\title{
Untangling reading strategies and reading skills in an ESL textbook
}

\author{
Rafael Zaccaron \\ Universidade Federal de Santa Catarina \\ rafaelzaccaron@gmail.com \\ Carlla Dall'Igna \\ Universidade Federal de Santa Catarina \\ carlla_dalligna@hotmail.com \\ Lêda Maria Braga Tomitch \\ Universidade Federal de Santa Catarina \\ leda@cce.ufsc.br
}

\begin{abstract}
Successful reading comprehension in $\mathrm{L} 2^{1}$ involves both lower and higher level processes, being dependant on both strategies and skills. These two components are often treated interchangeably or inconsistently in the literature and such inconsistency may affect the teaching of reading. In light of the above, this paper aims at analysing how strategies and skills are developed in a series of ESL textbooks. In order to do so, a framework was developed to classify the activities as sustaining reading strategies or reading skills. A quantitative analysis was also carried out in order to better understand the frequency each construct occurred in the textbooks. The results showed that strategies and skills are used interchangeably in the series. Furthermore, strategies outnumbered skills, no linearity was found between them, that is, there seemed to be no longitudinal process of working with strategies in a way to enable them to become skills in order to foster independent readers.
\end{abstract}

Keywords: reading strategies. reading skills. Textbook. ESL. reading comprehension.

\footnotetext{
${ }^{1}$ In this study second language (SL/L2) is being used interchangeably with foreign language (FL).
} 


\section{Resumo}

O sucesso da compreensão na leitura em L2 envolve tanto processos de baixo como de alto nível, sendo os mesmos dependentes de estratégias e habilidades. Esses dois conceitos são normalmente utilizados de forma intercambiável entre si e tratados de forma inconsistente na literatura, sendo que tal inconsistência pode vir a afetar o ensino de leitura. Com base nesse fato, esse artigo tem o objetivo de analisar como estratégias e habilidades são desenvolvidas em uma série de livros de inglês como segunda língua. Para alcançar tal objetivo, um framework foi desenvolvido para classificar as atividades que fomentam 'estratégias' ou 'habilidades' de leitura. Com o intuito de estabelecer a frequência de cada um desses conceitos na série de livros uma análise quantitativa foi realizada. Os resultados apontam que os conceitos de estratégias e habilidades são utilizados de forma intercambiável na série. Também, a presença de estratégias foi mais frequente do que habilidades e não há uma sequência linear entre esses dois conceitos, isto é, parece não haver um processo longitudinal de forma a trabalhar estratégias para que elas se tornem habilidades a fim de desenvolver leitores independentes.

Palavras-chave: estratégias de leitura. habilidades de leitura. livro didático. ISL. compreensão de leitura.

\section{Introduction}

Learning how to read and comprehend written texts is an important aspect of literacy and this idea can be extended to reading in a second language (L2). Reading comprehension, in turn, is a multicomponent and complex cognitive process that involves an interaction between the reader and the text (DANEMAN,1991; TOMITCH, 2009). Gagné et al. (1993) points out that successful reading comprehension is anchored on three pillars, namely, conceptual understanding, automated basic skills, and strategies. Conceptual understanding is composed of knowledge of the topic, schemata and vocabulary in relation to the text. Word decoding skills and the ability to construct propositions from strings of words are part of automated basic skills, and finally, strategies include "varying one's approach to reading depending upon one's goal and monitoring one's comprehension" (p. 269). Skills and strategies from this viewpoint 
integrate what is known as procedural knowledge, i.e. knowledge on how to read.

As observed by Gagné et al. (1993), such knowledge on how to read involves the execution of a set of componential processes both at the lower level, such as decoding and literal comprehension, and also at the higher level, such as inferential comprehension and comprehension monitoring. For reading to flow well and comprehension be achieved, readers need to automatize the first two processes as soon as possible so that attentional resources can be left for inferential comprehension and the reader can also monitor comprehension during reading.

Being one of the two main concepts for this study, reading strategies are defined as "deliberate, goal-directed attempts to control and modify the reader's effort to decode text, understand words and construct meanings of the text" (AFFLERBACH; PEARSON; PARIS, 2008, p. 368). This means that reading strategies are an attempt to make learners aware of the different components of the reading process. According to Alkhaleefah (2016), this definition for reading strategy is comprehensive and has already founded other studies in the last decade (ALKHALEEFAH, 2016, MANOLI; PAPADOPOULOU, 2012, SIMÃO; BARETTA, 2014, among others).

The second main concept, reading skills, is defined as "automatic actions that result in decoding and comprehension with speed, efficiency, and fluency and usually occur without awareness of the components or controls involved" (AFFLERBACH et al., 2008, p. 368). Therefore, one may say that reading skills are the actions a proficient reader takes while reading that they are often unaware of. These aforementioned definitions for both concepts, reading strategies and reading skills, adopted in this study, guided the construction of a framework to analyse an EFL textbook, as will be seen later on.

By virtue of being considered as pillars to successful reading comprehension, reading strategies and reading skills are seen as necessary for reading development (AFFLERBACH et al., 2008), what leads to the importance of providing reading instruction on both reading strategies and skills in order to facilitate reading comprehension. Such topic has been highlighted in the last decades by other studies (DUFFY, 2009, PEARSON; DOLE, 1988; PRESSLEY, 
2000), but the view of these two terms are not the same in all of them. Clearly, reading strategies and skills are currently not two definite concepts; they are often treated interchangeably or inconsistently (AFFLERBACH et al., 2008; MANOLI; PAPADOPOULOU, 2012) in the literature.

Based on the issues above, this paper aims at analysing how reading strategies and reading skills, as related but yet, individual concepts, are presented in an ESL (English as a second language) textbook, namely, the Interchange series. Moreover, considering sometimes conflicting information, this piece of research strives to clarify the differences between these concepts and suggests an approach to analyse the use of skills and strategies in a textbook. In order to do that, three research questions are addressed:

1- How are reading strategies and reading skills defined by the textbook? Are they treated as two related but different constructs?

2- How frequent are reading strategies and reading skills presented?

3- How are the instructions provided in the Teacher's Manual regarding reading strategies and reading skills?

\section{Review of literature}

\subsection{Reading strategies}

Although reading strategies have become the object of numerous studies in the reading field, a clear-cut definition widely adopted in this field remains elusive. Manoli and Papadopoulou (2012) and Afflerbach et al. (2008) pointed to the surge in the use of reading strategies linked to the following aspects of reading in the 90's: control and deliberate direction of behaviour, which are an integral part of reading strategies but might not contemplate all its idiosyncrasies as it can be noticed in the different uses of this concept in the literature and studies focusing on teaching strategies. 
Among some of the issues when trying to establish the clear difference between reading skills and reading strategies, Duffy and Roehler (1989) contributed to the discussion signalling the difference between conscious awareness and automatic use. Skills are linked to automatized response, whereas strategies refer to the development of metacognitive awareness. The authors also mention that through strategy instruction it is expected that reading strategies will be eventually used automatically by learners, which is in line with Manoli and Papadopoulou (2012).

Two important aspects raised by Duffy and Roehler (1989) are: a) strategy learning is a longitudinal process. Learners increasingly restructure instructional information to their existing schemata; and b) there should be consistent instructional messages so that all messages support strategic reading. These concepts, according to the researchers, should be considered by instructional material developers when designing textbooks.

Pressley and Afflerbach (1995), in a review on more than forty studies where think-aloud protocols were used, found many conscious and controlled reading processes: being aware of their purpose in reading, selective reading aimed at specific goals, making associations with prior knowledge, summary, word recognition, among others. These aspects are indicatives of strategy use by the participants who are aware of the components involved.

More recently, in the Brazilian context, Simão and Baretta (2014) conducted a study analysing the presence of strategies in English textbooks used in public schools of a city in Paraná, however, they did not analyse the presence of skills in the same books. They concluded that there were not enough strategies for the building of autonomous and skilled readers.

The aforementioned studies highlight the importance of teaching reading strategies to foster reading comprehension. However, there seems to be some disagreement regarding the concept of strategies and skills. Alkhaleefah's (2016) review study on the taxonomy of reading strategies showed that consensus has not been reached, but there seems to be an area of convergence and future studies "can be cross-referenced" (p.166), something that the present study aims at contributing. 


\subsection{Reading skills}

As mentioned earlier, for reading comprehension to occur in a fluent manner some aspects of the process need to be automatized, for instance, word decoding and literal comprehension. Duffy (2009) regards the ability to read fluently as a skill, that is, skilled readers must not "stop frequently to correct miscues" (p. 33). Although Duffy's book is directed to teaching reading in the L1 to children, most concepts and activities presented are also relevant for $\mathrm{L} 2$ teaching.

Pearson and Dole (1988), in a review of studies in the area, and possibly keeping the terminology used by the authors of the studies examined, refer to some strategies as skills. They change the approach used to the terms as different pieces of research are analysed. The interchangeable use of the terms reading strategies and reading skill seems to be a pattern, not an exception.

Duffy and Roehler (1989), when discussing the difficulties in teaching reading strategies, also pointed to the fact that most teachers thought that skills and strategies were the same. After reviewing more recent articles, this view may be extended to today's teachers as well, considering that there seems to be disagreement on the clear distinction between reading strategies and reading skills.

All in all, considering the different views on reading skills thereof, this piece of research adopts the definition of these concepts provided by Afflerbach et al. (2008) in order to support the proposed framework to analyse reading activities in EFL textbooks, as already presented in the introduction.

\section{Method}

\subsection{Instruments and procedures}

The Interchange Book Series was analysed as a means of investigating how strategies and skills are presented in the textbook. Interchange is a textbook series published by Cambridge Press for adult and young-adult learners of English as an L2 from the beginning 
to the high-intermediate level. The reason for choosing the Interchange series was because this series is sold worldwide and it has been in the market for over twenty-five years. Currently, Interchange is in its fourth edition, with four books integrating the series (Intro, book 1, book 2 and book 3). Each book has sixteen units, with one reading activity at the end of each unit. The first book, Intro, does not follow this pattern, since it has no reading activity up to the fifth unit, nevertheless, it was also included in the analysis. The reading activities are quite similar in all books, organized in the following manner: a TIP, which contains some suggestions to the teacher on how to initiate the reading activity (it was present only in the teacher's manual), a prereading section, a reading section, and a post-reading section. Unlike other ESL textbooks, the texts presented in the reading sections are texts that are simplified and non-authentic. In the teachers' manual, the learning objectives of each specific reading activity are stated, as well as instructions to the teacher on how to conduct the reading activity.

In this study, three reading activities of each of the four books were analysed, totalizing 12 reading activities. The rationale behind the choice of the units was the presence of a similar gap between the units within the same book, and, at the same time, different units of each book in order to have a better overview of reading activities instead of having always the same units from different books. For example, for book 1, units 1,8 and 16 were chosen; for book 2, units 2, 9 and 15 . However, due to the lack of reading activities in the Intro Book up to the fifth unit, some units were swapped; for instance, unit 5 of the Intro book was the first unit of that book to be analysed. Based on that, the units chosen to the study were: Intro - units 5, 10 and 13; Book 1 units 1, 8 and 16; Book 2 - units 2, 9 and 15; and Book 3 - units 3, 7 and 14 .

After the selection was established, each reading activity was carefully read and analysed. The teacher's manual was also taken into account in order to better understand the instructions given to teachers and how they related to strategies and skills as defined in this study. Therefore, it should be clear that the classification of reading strategies and reading skills in the Interchange Series, here presented, does not reflect the terminology found in the analysed Interchange books, unless stated as such as a means of comparison. 


\subsection{Framework for data analysis}

Based on the literature reviewed in this study a framework for data analysis was devised according to which a reading activity from the textbook being analysed would fall into one of the following three categories: 'reading strategy', 'reading skill' or 'reading strategy and skill'. First, a reading activity would be classified as a 'strategy' when it met most or all of the following characteristics: a) the activity attempts to control and modify the reader's effort to construct meanings of text; b) the instruction suggests time constraints for activity completion; c) the teacher is instructed to explicitly explain the reading activity and help students to perform it through the use of some techniques, such as modelling ${ }^{2}$ and reviewing; d) the teacher is instructed to make use of metalanguage, raising students' awareness on linguistic aspects present in the text. Second, it would be classified as a 'skill' when it met most or all of the following characteristics: a) the instructions require students to read the text and complete the activities having no modelling; b) the instructions for the activity combine what students already know with no teaching guidance; c) the activity does not separate the instruction as a means of providing steps for the completion of it in a controlled fashion. Last, it would be classified as both 'reading strategy and skill' when a given activity belonged to both previous categories. For instance, making connection can present the characteristics of a reading strategy when this activity requests the teacher to instruct how to make the connection, that is, providing a model in a controlled fashion. On the other hand, the same activity can be classified as a skill when the instructions in the textbook state that students should read the text and complete the activity which involves making a connection.

\footnotetext{
${ }^{2}$ Modelling is here understood as "what teachers do to show novice learners how to do something they do not know how to. It is a particularly important instructional action because by modelling the teacher reduces the ambiguity associated with tasks" (DUFFY; ROEHLER, 1989, p. 145).
} 


\section{Results and discussion}

The analysis of the selected twelve reading activities placed them into three different categories, as mentioned before: reading strategies, reading skills, or as both reading strategies and skills. The following table presents some samples and the classification of those activities, considering keywords based on the instructions existent in the Teacher's manual and the textbooks.

Table 1 - Classification and samples of Interchange series' reading activities.

\begin{tabular}{|c|c|}
\hline Activities & Instructions in the Teacher's Manual \\
\hline $\begin{array}{l}\text { (1) Prior } \\
\text { knowledge } \\
\text { activation } \\
\text { / Strategy }\end{array}$ & $\begin{array}{l}\text { For example, in a text about the meaning of English } \\
\text { names: "Ask: 'What English names do you like? Why?' } \\
\text { Elicit answers" (RICHARDS et al., 2013b, p.T7). }\end{array}$ \\
\hline $\begin{array}{l}\text { (2) Text } \\
\text { prediction based } \\
\text { on title/ } \\
\text { Strategy }\end{array}$ & $\begin{array}{l}\text { "Focus Ss' attention on the title of the reading. Ask: } \\
\text { 'What do you think this article is about?'. Elicit ideias" } \\
\text { (RICHARDS et al., 2013b, p.T7). }\end{array}$ \\
\hline $\begin{array}{l}\text { (3) Scanning/ } \\
\text { Strategy }\end{array}$ & $\begin{array}{l}\text { "Ss scan the text quickly to find examples of names. } \\
\text { Ask: 'Do you know any people with these names? } \\
\text { What are they like?"' (RICHARDS et al., 2013b, p.T7). }\end{array}$ \\
\hline $\begin{array}{l}\text { (4) Skimming/ } \\
\text { Strategy }\end{array}$ & $\begin{array}{l}\text { "Explain the pre-reading task [Skim the conversation. } \\
\text { Write the name of the correct person under each } \\
\text { picture]. Explain that skim means 'to read quickly to } \\
\text { find general information"” (RICHARDS et al., 2013a, } \\
\text { p.T35) }\end{array}$ \\
\hline $\begin{array}{l}\text { (5) Problem } \\
\text { solving/ } \\
\text { Strategy } \\
\end{array}$ & $\begin{array}{l}\text { "Explain the task. Ss read the article silently. Remind } \\
\text { students to try to guess the meaning of any words they } \\
\text { don't know" (RICHARDS et al., 2013b, p.T111). }\end{array}$ \\
\hline $\begin{array}{l}\text { (6) Comparing } \\
\text { and contrasting/ } \\
\text { Strategy }\end{array}$ & $\begin{array}{l}\text { "Explain the task. Give one or two examples. Ss } \\
\text { complete the tasks individually. As Ss work, draw the } \\
\text { chart on the board" (RICHARDS et al., 2013b, p.T7). }\end{array}$ \\
\hline $\begin{array}{l}\text { (7) Inferencing } \\
\text { (metalanguage) } / \\
\text { Strategy }\end{array}$ & $\begin{array}{l}\text { "Explain the task. Elicit that words like it, their, her } \\
\text { and that are pronouns. Pronouns refer to a previous } \\
\text { noun. Other phrases can also refer to earlier } \\
\text { information." (RICHARDS et al., 2013d, p.T21). }\end{array}$ \\
\hline $\begin{array}{c}\text { (8) Making } \\
\text { connections/ } \\
\text { Strategy \& Skill }\end{array}$ & $\begin{array}{l}\text { As a strategy: "Explain the task. Model the first words } \\
\text { as an example. Ask Ss to find the word confront in the } \\
\text { article. Then ask: do you think confront is a verb, }\end{array}$ \\
\hline
\end{tabular}




\begin{tabular}{|c|c|}
\hline Activities & Instructions in the Teacher's Manual \\
\hline & $\begin{array}{l}\text { adjective or a noun? (Answer: a verb). Then elicit the } \\
\text { answers." (RICHARDS et al., 2013c, p.T105). } \\
\text { As a skill: "Ss read the text silently and check the } \\
\text { correct answer." (RICHARDS et al., 2013c, p.T63). }\end{array}$ \\
\hline $\begin{array}{l}\text { (9) Finding the } \\
\text { main idea, } \\
\text { important facts } \\
\text { and supporting } \\
\text { details/ }\end{array}$ & $\begin{array}{l}\text { As a strategy: "Explain the task. Point out the flow } \\
\text { charts and read the sentences...Ss will add information } \\
\text { from the article to complete the flow charts" } \\
\text { (RICHARDS et al., 2013c, p.T49). }\end{array}$ \\
\hline Strategy \& Skill & $\begin{array}{l}\text { As a skill: "Ss read the text silently and check the } \\
\text { correct answer." (RICHARDS et al., 2013c, p.T63). }\end{array}$ \\
\hline $\begin{array}{l}\text { (10) Reading for } \\
\text { details/specific } \\
\text { information/ } \\
\text { Strategy \& Skill }\end{array}$ & $\begin{array}{l}\text { As a strategy: "Explain the task. Ss read the text more } \\
\text { carefully to complete the chart. Point out that they can } \\
\text { find the answers quickly by looking for the phrases in } \\
\text { the chart" (RICHARDS et al., 2013a, p.T35). } \\
\text { As a skill: "Tell Ss to read the article again and make } \\
\text { notes in the chart" (RICHARDS et al., 2013c, p.T63). }\end{array}$ \\
\hline $\begin{array}{l}\text { (11) Extensive } \\
\text { Reading/ } \\
\text { Strategy \& Skill }\end{array}$ & $\begin{array}{l}\text { As a strategy: "Explain the first part of the task. Ss read } \\
\text { the interview individually. Explain the second part of } \\
\text { the task" (RICHARDS et al., 2013a, p.T69). } \\
\text { As a skill: "Ss read the article again. Ss complete the } \\
\text { task individually" (RICHARDS et al., 2013d, p.T21). }\end{array}$ \\
\hline $\begin{array}{l}\text { (12) Fluency/ } \\
\text { Skill }\end{array}$ & $\begin{array}{l}\text { "Tell them they don't need to understand every word" } \\
\text { (RICHARDS et al., 2013c, p.T63). }\end{array}$ \\
\hline $\begin{array}{c}\text { (13) Making } \\
\text { Inferences/ Skill }\end{array}$ & $\begin{array}{l}\text { "Have you ever seen a Bollywood movie? If so, how } \\
\text { did you like it?" (RICHARDS et al., 2013d, p.T97). }\end{array}$ \\
\hline
\end{tabular}

Source: Elaborated by the authors

As specified in table 1, in prior knowledge activation (1), the teacher induces students to brainstorm some ideas related to the topic of the reading activity. It is, therefore, a goal directed activity that attempts to control and modify the reader's effort to construct meanings of text. Based on these reasons and on the definitions of reading strategies and reading skills adopted in this study, prior knowledge activation (1) was classified as a reading strategy. 
Similarly, text prediction based on title (2) is an activity that aims at preparing the students to perform the reading through the title. Considering that it can be seen as a deliberate action that helps students to predict the text content, it was also classified as a strategy.

Throughout each unit teachers are explicitly instructed to ask students to use both scanning (3) and skimming (4) as a manner to facilitate the development of the reading activity, since the former requires readers to obtain specific information of the text, and the latter instructs to quickly understand the gist of it. Sometimes, the teacher is even instructed to explain the meaning of skimming or scanning a text, as in the example in Table 1. For these reasons, scanning (3) and skimming (4) are portrayed in the texbook as goal-directed attempts to control the readers' effort to understand the text. Therefore, they were both classified as strategies.

In a similar manner, activities containing problem-solving (5) and comparing and contrasting (6) usually aimed at raising students' awareness of reading in a strategic way. The teacher is instructed to explicitly explain the reading activity using some specific strategies, such as remembering students to guess the meaning of words they do not know and modelling some structures to help them to complete the activity. Therefore, because they attempt to ease the reader's effort to understand the text, they were both classified as reading strategies.

In inferencing (7), as the example in Table 1 shows, there is the clear use of metalanguage, raising students' awareness on the referents. It represents, therefore, an attempt to make learners aware of the different components of the reading process, and, for this reason, it was classified as a strategy.

The analysis of the reading activities containing making connections (8) signalled that it is used to develop both a reading strategy and a reading skill. When students have to link the information of the text to other texts with instructions to do so it was classified as a strategy, as it represents a goal direct attempt to construct meaning from the text. When the reader had to accomplish the same activity but no instruction on the process was present it was classified as a skill. Finding the main idea, important facts and supporting details (9) also indicated that it was used as a reading strategy and as a reading skill in different moments. It was classified as a strategy when the activities suggested teachers to indicate how to find the required information, 
pointing out a keyword in the text for the completion of the activity. The process would happen, therefore, in a controlled manner. Whereas the same component was also classified as a skill when no modelling nor any instruction targeting the process involved in that reading activity were provided, as seen in table 1 .

Reading for detail (10), also cited as reading for specific information, was classified both as a reading strategy and as a reading skill. As a strategy, when it made use of one or a combination of the following aspects: teacher's modelling, time constraint for activity completion or metalanguage. These activities are controlled or raise awareness about the process, which is linked to strategies. It was also classified as a skill when the activity did not involve any of the aforementioned instructions, expecting readers to comprehend the text on their own in order to answer the comprehension questions in an automatic fashion.

Extensive reading (11) was classified as a strategy when learners were first introduced to the reading activities. The notion of asking readers to read the whole text first and then proceed to the next activity, that is, extensive reading, indicates the intention to ease the possible burden of answering comprehension questions about an L2 text. The rationale for this classification is especially based on fact that in the Intro book activities involving extensive reading required the teacher to explain them. In book 3 there is an occurrence of extensive reading. It was classified as a skill considering it was found in the last book of the series and the instructions suggested students to read the text again and answer comprehension questions, as seen in table 1 .

Fluency (12) was classified as a skill. The classification of it as a skill is based on the process the instruction intends to develop. It asked teachers to remind students they should not worry about every word they do not understand in the text (see table 1). Making inferences (13) was classified as a skill due to the processes involved in establishing connections between the text and the reader's own reality. It also considered how the activities involving making inference did not split these processes expecting the reader to proceed automatically as a skill.

Next, the three research questions posed in this study are retaken and discussed in the light of the relevant literature. 
Question 1- How are reading strategies and reading skills defined by the textbook? Are they treated as two different constructs?

The teacher's manual does not provide an explicit definition of reading strategy nor of reading skill. The overview of the book, in its very beginning, presents the reading section affirming that it aims at "developing a variety of reading skills, such as reading for main ideas, reading for details, and inferencing” (RICHARDS et al., 2013, p. xv). As noted, there is no mention of strategies, and this is a pattern that could be noticed throughout the units.

Similarly, the learning objective, stated in each reading activity, always mentions the development of skills, but not strategies. For example, in the reading activity of unit 15 - Book 2, the learning objective is "develop skills in skimming, scanning, and guessing meaning from context" (RICHARDS et al., 2013c, p. 105). According to the instructions presented for this activity, all three procedures require controlled actions that are goal-directed attempts in order to help to understand the text; and these, according to Afflerbach et al. (2008), are characteristics of strategies. What is found in the Interchange series, therefore, is consistent with previous research, that is, reading strategies and reading skills are used interchangeably by many practitioners and researchers (MANOLI; PAPADOPOULOU, 2012, PEARSON; DOLE, 1988).

Question 2- How frequent are reading strategies and reading skills presented?

The reading activities are organized in the following fashion: pre-reading, reading, and post-reading activities. This echoes the advice given by other researchers in the reading field, as for example Aebersold and Field (1997) and Tomitch (2009), among others. In regards to strategies, they were found only in pre-reading and reading activities. On the other hand, skills were present only in the reading and post-reading phases. In relation to strategies, table 2 shows how they are quantified along the units analysed according to the framework proposed in the present study. 
Untangling reading strategies and reading skills...

Table 2. Number of reading strategies in the Interchange series.

\begin{tabular}{|c|c|c|c|c|c|}
\hline & Strategies & Intro & 1 & 2 & 3 \\
\hline \multirow[b]{3}{*}{ 当 } & Scanning & & 1 & & \\
\hline & Skimming & & 1 & & \\
\hline & $\begin{array}{l}\text { Reading for details/specific } \\
\text { information }\end{array}$ & & 1 & & \\
\hline \multirow{4}{*}{ 总 } & Prior knowledge activation & 4 & 3 & 3 & 3 \\
\hline & Text prediction based on title & & 1 & & \\
\hline & Scanning & & 3 & & 2 \\
\hline & Skimming & 1 & & 2 & 1 \\
\hline \multirow{8}{*}{ 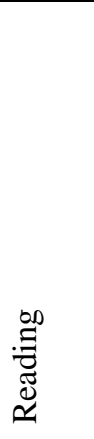 } & Problem solving & & 2 & & \\
\hline & Comparing and contrasting & & 1 & & \\
\hline & $\begin{array}{l}\text { Finding the main idea, important } \\
\text { facts and supporting details }\end{array}$ & & 1 & & 2 \\
\hline & $\begin{array}{l}\text { Reading for details/specific } \\
\text { information }\end{array}$ & 2 & 2 & & 1 \\
\hline & Extensive Reading & 3 & & & \\
\hline & Scanning & 1 & & & \\
\hline & Making connections & & & 2 & \\
\hline & Inferencing (metalanguage) & & & & 1 \\
\hline Total & & 11 & 16 & 7 & 10 \\
\hline
\end{tabular}

Source: Elaborated by the authors

The book Intro concentrated $25 \%$ of the strategies of the sample analysed. Book 1 had the highest number of strategies, with $36,3 \%$. Book 2 had the lowest number, with $16 \%$. The last book, book 4 , concentrated $22,7 \%$ of the total number of strategies found in the series.

The most common strategy found in all the units analysed is prior knowledge activation. This strategy was normally presented in the same way: teacher-centred, referring to the title of the text or pictures. Scanning and skimming, strategies commonly found in books (DUFFY, 2009), were also frequent in the units of all books analysed. One of the strategies that stands out is extensive reading. It is an odd choice to use this strategy as a means to familiarise readers with the text, also considering that previous studies in the area reviewed in this paper do not contemplate such strategy. Furthermore, bearing in mind that extensive reading was found in the Intro book, it could be 
detrimental to $\mathrm{L} 2$ beginners as reading in a second language could offer much of a burden for learners who have not mastered syntax and vocabulary yet.

A positive aspect of the Interchange series is that it offers a varied use of reading strategies throughout all books (despite the fact that they are called 'skills' in the series), such as problem-solving, comparing and contrasting, reading for details/specific information, etc. In this vein, Afflerbach et al. (2008) reinforce the importance of teaching students different strategies.

Regarding skills, table 3 shows how they are quantified along the units analysed.

Table 3. Number of reading skills in the Interchange series.

\begin{tabular}{|l|l|c|c|c|c|}
\hline & \multicolumn{1}{|c|}{ Skill } & Intro & $\mathbf{1}$ & $\mathbf{2}$ & $\mathbf{3}$ \\
\hline \multirow{5}{*}{ Reading } & Fluency & & & 1 & \\
\cline { 2 - 6 } & Reading for details & & 2 & 2 & 1 \\
\cline { 2 - 6 } & $\begin{array}{l}\text { Finding the main idea, important } \\
\text { facts and supporting details }\end{array}$ & & & 1 & \\
\cline { 2 - 6 } & Making connections & & & 1 & \\
\cline { 2 - 6 } & Extensive reading & 3 & 3 & 3 & 3 \\
\hline $\begin{array}{l}\text { Post- } \\
\text { reading }\end{array}$ & Making Inferences & 3 & 5 & 8 & 5 \\
\hline Total & & & & & 1 \\
\hline
\end{tabular}

Source: Elaborated by the authors

As table 3 shows, the reading phase that was used the most to develop skills is the post-reading phase. They all attempt to make the reader establish a connection with their reality, which corresponds to the aim of a post reading activity (TOMITCH, 2009). Besides, there is no control involved in the way the instructions present this activity. However, the format the activity is planned is almost the same in all units analysed. It is always an oral activity either performed in pairs or groups.

Of all the skills found in the sample analysed, the Intro book concentrated only $14,3 \%$ of them. This is problematic in a sense, because the skills are only developed during post reading activities in the units analysed. Although the fact that L2 beginners would initially be more exposed to strategies was expected, the attempt to teach 
reading skills could start with other activities at this level in order to foster a strategic autonomous reader.

Book 1, with $23,8 \%$ of the skills analysed, presented skills in post reading activities, but also worked with reading for details as a skill twice. It is interesting to note that book 1 already worked with this process as a skill, thus one would assume that the learner could have mastered it through the Intro book. This finding indicates that there is no linearity between the presentation of skills and strategies.

The highest number of skills were found in book 2 , where $38,1 \%$ of the skills of the sample were present. The progressive teaching of skills from the introductory book (Intro) to this one is consistent with the literature (DUFFY; ROEHLER, 1989) as it has the goal to foster independent readers. Another positive aspect found in book 2 was the varied set of skills that come forth, such as: fluency, reading for details and finding the main idea, important facts, and supporting details.

Finally, book 3 , with $23,8 \%$ of the skills analysed, showed a decline in skills in relation to the previous book of the series. This is a fact that contradicts not only the literature reviewed, which mentions the importance of the progressive teaching of skills to foster independent readers (DUFFY; ROEHLER, 1989), but also breaks the linear progress from books Intro to 2. Also important to note is that there was an increase in the number of strategies presented in book 3 in relation to book 2. Despite the small number of units analysed from each book, this finding reinforces what is commonly found in the literature, that reading strategies and reading skills are used interchangeably (PEARSON; DOLE, 1988, MANOLI; PAPADOPOULOU, 2012) by many practitioners and researchers.

Question 3- How are the instructions provided in the teacher's manual regarding reading strategies and reading skills?

For every reading activity, Interchange offers the learning objective of that particular unit at its beginning. Not only once, from the sample of units analysed, was it noticed that the reading strategy or reading skill focused did not match the description of the instruction. In unit 15 of book 2, for example, the learning objective is: "develop 
skills in skimming, scanning, and guessing meaning from context" (RICHARDS et al., 2013, p.105); however, after careful analysis of the instructions, no activity related to developing scanning could be found. This might indicate that besides the two concepts being used interchangeably, there is also discrepancy between the reading objectives and the activities proposed.

Regarding the presentation of strategies, an important aspect raised by some authors is learner's metacognitive awareness (DUFFY; ROEHLER, 1989). Despite being relevant, this aspect appeared only in book 1 as a tip to the teacher: "explain that in real life people read in different ways for different purposes. For example, they read manuals or recipes slowly and in detail, but they skim magazines or scan telephone book more quickly" (RICHARDS et al., 2013 p. 7). Based on Pearson and Dole (1988)'s findings validating the need for explicit explanation of the metacognitive processes of strategies, it is relevant to question the lack of more strategies such as these.

\section{General discussion}

The mismatch between the concepts of strategies and skills was a constant fact when reviewing the literature and also in the instructions of the reading activities present in the Interchange series. This issue lead to the adoption of a new framework brought in this article, based on the work of Afflerbach et al. (2008). It is hoped that this framework might help the future analysis of other researchers that intend to untangle and study further the application of reading strategies and reading skills in textbooks.

Regarding the analysis of the Interchange series, a fruitful aspect was the presence of activities that can develop, both, reading strategies and reading skills. In relation to reading strategies, the results showed a higher number of them in the first two books. This finding is in line with the literature as it is expected that beginners need the highest exposure to strategies, since the processes are not automatized yet (DUFFY; ROEHLER, 1989). With practice, it is expected that some strategies become automatic, probably justifying the decline of number of strategies in the two last books. However, it was also 
noticed that reading strategies are only developed during pre-reading or reading activities. Duffy (2009) points out that strategies can also be developed in post-reading activities, but Interchange does not tackle this reading component on that stage.

When it came to skills, the results showed a decline on the development of skills in book 3, which also presented more strategies than book 2. This finding is incongruent with the longitudinal process of strategies becoming skills (AFFLERBACH et al., 2008, MANOLI; PAPADOPOULOU, 2012). However, all in all, a varied set of strategies and skills was present in the reading activities analysed.

In relation to the use of the Teacher's Manual of EFL textbooks, Simão and Baretta (2014) advise that they always should be used by teachers from a critical perspective. However, it is a fact that some teachers will simply follow the manual. Therefore, the presentation of strategies and skills in fairly the same fashion, as seen throughout the reading activities within the Interchange series, in what could initially be seen as a means of fostering assimilation through repetition, does not appear to lead to the development of an independent skilled reader from a longitudinal perspective (AFFLERBACH et al., 2008). Based on this analysis, it seems that it would be necessary a critical teacher to adapt the reading activities in order that reading strategies could become reading skills.

An important aspect raised by few researchers is the need for explicit explanation of cognitive processes - metacognition - activated during reading by a teacher (AFFLERBACH et al., 2008, DUFFY; ROEHLER, 1989). This feature seems to be overlooked in the Interchange series with few activities focusing in raising awareness of metacognitive processes considering the overall number of activities.

\section{Conclusion}

The initial purpose of this study was to analyse how reading strategies and reading skills were shown in the instructions of an EFL textbook. As the research progressed, it was clear the tangle between these two concepts, not only in the literature, but also in the reading activities within the Interchange series. As a result, a framework to 
analyse the reading activities was developed which made it possible to untangle the two concepts separately. Thus, allowing not only for the categorisation of reading strategies and reading skills, but also the possibility to view them quantitatively in the twelve units of the series analysed. Therefore, we believe this framework may be used for the analyses of other EFL textbooks.

Overall, the results of this study indicated, firstly, a mismatch between the concepts of reading strategies and reading skills in Interchange. These two terms were used interchangeably in the books of the series analysed. Secondly, there seemed to be no line of progress for reading strategies and skills concerning the number of activities and or the respective book where they were found. Finally, the instructions in the Teacher's Manual sometimes did not match the reading goal intended.

This study, as a first step, presents a few limitations due to the small selection of units analysed. However, this is a fruitful area for other studies that would follow the same pattern of the present study and analyse how reading strategies and skills are presented in different EFL textbooks.

\section{References}

AEBERSOLD, Jo Ann; FIELD, Mary Lee. From reader to reading teacher issues and strategies for second language classrooms. Cambridge: Cambridge University Press, 1997.

AFFLERBACH, Peter; PEARSON, David; PARIS, Scott. Clarifying differences between reading skills and reading strategies. The Reading Teacher, v. 61, n. 5, p. 364-373, 2008.

AFFLERBACH, Peter; et al. Reading: what else matters besides strategies and skills?. The Reading Teacher, v. 66, n. 3, p. 440-448, 2013.

ALKHALEEFAH, Tarek. Taxonomies in L1 and L2 reading strategies: a critical review of issues surrounding strategy-use definitions and 
Untangling reading strategies and reading skills...

classifications in previous think-aloud research. The Reading Matrix, v. 16, n. 2, p. 162-226, 2016.

DANEMAN, Meredyth. Individual differences in reading skills. In: BARR, Rebecca et al. (Orgs.). Handbook of reading research, v.2. New York: Longman, 1991. p. 512-538.

DUFFY, Gerald G.; ROEHLER, Laura R. Why strategy instruction is so difficult and what we need to do about it. In: MCCORMICK, Christine B.; MILLER, Gloria; PRESSLEY, Michael. (Orgs.). Cognitive strategy research: from basic research to educational applications. New York: Springer-Verlag, 1989. p. 133-154.

DUFFY, Gerald G. Explaining reading: a resource for teaching concepts, skills and strategies. New York: Guilford Press, 2009.

GAGNÉ, Ellen D., YEKOVICH, Carol W.; YEKOVICH, Frank R. Reading. In: (Orgs.). The cognitive psychology of school learning. New York: Harper Collins College Publishers, 1997. p. 267312.

MANOLI, Polixeni; PAPADOPOULOU, Maria. Reading strategies versus reading skills: two faces of the same coin. Procedia: Social and Behavioral Sciences, v. 46, p. 817-821, 2012.

PEARSON, David; DOLE, Janice, A. Explicit comprehension instruction: a review of research and a new conceptualization of instruction. The Elementary School Journal, v. 88, n.2, p. 151-165, 1987.

PRESSLEY, Michael; AFFLERBACH, Peter. Verbal protocols of reading: the nature of constructively responsive reading. Hillsdale, $\mathrm{NJ}$ : Lawrence Erlbaum Associates, 1995.

PRESSLEY, Michael. What should comprehension instruction be the instruction of?. In: KAMIL, M et al. (Org.) Handbook of Reading Research, v. 3. New York: Routledge, 2000. p. 545-562. 
RICHARDS, Jack. Interchange Intro, 4th ed. Cambridge: Cambridge University Press, 2013a.

RICHARDS, Jack. Interchange 1, 4th ed. Cambridge: Cambridge University Press, 2013b.

RICHARDS, Jack. Interchange 2, 4th ed. Cambridge: Cambridge University Press, 2013c.

RICHARDS, Jack. Interchange 3, 4th ed. Cambridge: Cambridge University Press, 2013d.

SIMÃO, Likelli; BARETTA, Luciane. Reading strategies in English textbooks. In: TUMOLO, Celso H.S.; BECK, Magali S.; COULTHARD, Malcolm. (Orgs.). ECHOES: reflections on language and literature. Florianópolis: Editora da UFSC, 2014. p. 23-34.

TOMITCH, Lêda Maria B. Aquisição de leitura em língua inglesa. In: LIMA, Candido D. Ensino e aprendizagem de língua inglesa: conversa com especialistas. São Paulo: Parábola Editorial, 2009. p.191-201.

VEENMAN, Marcel V. J.; VAN HOUT-WOLTERS, Bernadette H. A. M.; AFFLERBACH, Peter. Metacognition and learning: conceptual and methodological considerations. Metacognition and Learning, v.1, n. 1, p. 3-14, 2006.

Recebido em: 10/10/2017

Aceito em: 08/02/2018

Título: Análise de estratégias e habilidades de leitura em um livro didático de inglês como segunda língua 